\title{
研究対象としての保険判例の射程に 関する一視点
}

—— 租税法・競争法・情報法の判例を素材として—

泉 裕 章

\section{ロアブストラクト}

近時, 生命保険分野では, 講学上の保険法に関する判例件数が大きく減少 していると言われている。こうした状況は, 保険法学界の研究対象の減少に もつながりかねない。そこで, 同学界の研究対象の裾野を拡げるべく, 保険 法の周辺の法分野に存在する保険判例を研究対象として取り扱うことも一考 に值するように思われる。

本稿では, 上のような問題意識および目的の下, 具体的には, 周辺の法分 野として, 租税法, 競争法, 情報法の 3 つを取り上げたうえ, 各分野に存在 する保険判例（分野ごとに各 1 件）の紹介および考察を行った。

その結果, 各保険判例の中には, 保険法学界として今後の検討に值する重 要な指摘が含まれているという結論を得た。このことは, 講学上の保険法の 研究にあたって, その他の周辺法分野も含めた保険判例を比較参照すること が，有益な手法の 1 つであり得ることを示唆している。

\section{ロキーワード}

保険概念, カルテル，保険金支払問題

* 令和元年 9 月18日の日本保険学会関東部会報告による。

/ 令和元年11月 1 日原稿受領。 


\section{I . はじめに}

\section{1. 本稿の問題意識と目的}

近時, 生命保険分野では, 講学上の保険法に関する判例 ${ }^{1)}$ 件数が大きく減 少していると言われている。その要因としては種々の事柄が挙げられるが, おそらく，そのうちの1つには，一般社団法人生命保険協会が運営する生命 保険相談所に設けられた裁定審査会の利用増加が含まれるであろう。この点, 公益財団法人生命保険文化センターが発行している『生命保険判例集』の掲 載判例件数と裁定審査会への申立件数を年 (度) 別 ${ }^{2}$ に見ると, 下表のとおり となっている゙๋。

\begin{tabular}{|c|r|r|r|r|r|r|r|r|r|}
\hline 年(度) & 2001 & 2002 & 2003 & 2004 & 2005 & 2006 & 2007 & 2008 & 2009 \\
\hline 判例 & 151 & 137 & 137 & 142 & 139 & 121 & 96 & 109 & 112 \\
\hline 申立て & 4 & 14 & 16 & 24 & 37 & 25 & 40 & 82 & 122 \\
\hline
\end{tabular}

\begin{tabular}{|c|r|r|r|r|r|r|r|r|r|}
\hline 年(度) & 2010 & 2011 & 2012 & 2013 & 2014 & 2015 & 2016 & 2017 & 2018 \\
\hline 判例 & 81 & \multicolumn{7}{|c|}{ 『生命保険判例集』未発行 } \\
\hline 申立て & $172^{4)}$ & 260 & 208 & 202 & $194^{5)}$ & 312 & 355 & 375 & 324 \\
\hline
\end{tabular}

1）本稿では, 最高裁判例, 下級審裁判例の別を問わず, 一律に「判例」という 語を使用する。また, 本稿では, 主として生命保険分野の判例を取り扱う。

2) 2001 (平成13)年(度) から 2018 (平成30)年(度)まで。『生命保険判例集』の掲 載判例件数は年別, 裁定審査会への申立件数は年度別。

3）公益財団法人生命保険文化センターのホームページおよび一般社団法人生命 保険協会『SR 報告書2019』24頁をもとに，筆者が作成。

4）指定紛争解決機関として業務を実施（一般社団法人生命保険協会・前揭注3） 24頁)。

5）苦情処理手続きの案内の徹底等, 運営を見直し（一般社団法人生命保険協 会・前掲注3)24頁)。 
2011(平成23)年から先の『生命保険判例集』は未発行であるが，上の件数 推移を見る限り，同判例集の掲載判例件数が減少傾向を辿ることは想像に難 くない。そうだとすれば，このことは，すなわち，保険法学界（以下，特に 断らない限り，単に学界という）の研究対象が減少するということをも意味 する。無論，学界の研究対象は判例だけではない。しかし，それが重要な研 究対象の1つであることは疑いようがない。そうすると, 学界としては, こ うした現実に対し，研究対象の裾野を拡げるべく，何らかの対策を施すこと も必要となってくるように思われる。これが本稿の問題意識である。

この点, 講学上の保険法の研究領域につき,「私保険に関する法分野とし ては，保険契約法，保険監督法が主要なものである」゙)ことを前提にした場

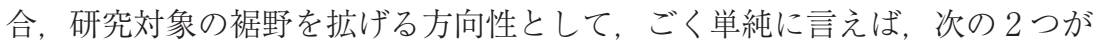
考えられる。1つは, 大きく増加している裁定審査会への申立事件を研究対 象として取り扱うことである。もう1つは，従来，主な研究領域とされてき た保険契約法あるいは保険監督法の枠を少し飛び出し，その周辺の法分野に 関する判例を研究対象として取り扱うことである。本稿は，このうちの後者 の方向性につき，1つの視点を提示することを目的とする。

もっとも，学界が，これまでの間，こうした事柄について何ら意識してこ なかったわけでないことはもちろんである。例えば，山下友信教授は，保険 の法的定義に関する文脈ではあるが，前述の引用部分に続けて，「税法をは じめとする様々な法分野で保険という概念が用いられている」 ${ }^{7)}$ と述べる。 また，別冊ジュリスト『保険法判例百選』（2010年・有斐閣）に掲載された 判例全110件のうち, 1 件目は租税法に関する事件 ${ }^{8)}$ であり, 最後の 2 件は 国際私法 (準拠法) に関する事件 ${ }^{9)}$ である。こうしたことからすれば，本稿

6）山下友信『保険法(上)』6 頁 (2018年 ·有斐閣)。

7）山下·前掲注6) 6 頁。

8）東京地判平成20年11月 27 日判時 2037 号 22 頁, 評釈, 後藤元「ファイナイト再 保険の課税上の取扱い」別冊ジュリ『保険法判例百選』4～5 頁（2010年・有 斐閣）。

9）東京地判昭和52年 5 月 30 日判時8 80 号79頁，金判542号32頁，評釈，栗田和彦 
研究対象としての保険判例の射程に関する一視点

の問題意識および目的は，学界における従前の努力の単なる後追いに過ぎな いかもしれない。しかし，仮に単なる後追いであるとしても，後記 I - 2 の 要領に基づいて取り上げる判例は, 従来, 保険法の学界において必ずしも大 きく取り上げられてこなかったように思われることから，こうした点に本稿 の意義を見出しつつ，論述を進めることとしたい。

\section{2. 論述の要領}

本稿は, 上で述べた目的を踏まえ, 周辺の法分野に関する判例として, 租 税法 (II), 競争法 (III), 情報法 (IV)の各判例を例示する。具体的には, 次の とおりである。すなわち, 租税法 (II)については, 一時払終身保険の保険概 念該当性を巡るアメリカの一判例（およびこの判例を取り上げたわが国の論 稿）を取り上げる。競争法 (III) については, 傷害保険のカルテルを巡る中国 の一審決 ${ }^{10)}$ を取り上げる。情報法 $(\mathrm{IV})$ については, 保険会社が監督官庁に 対して提出した報告書に関する，行政機関の保有する情報の公開に関する法 律（以下，行政機関情報公開法という）に基づく開示可否を巡るわが国の一 判例を取り上げる。最後に，まとめと残された課題 $(V)$ について言及する。

なお, 本稿の目的に照らし, あるいは, 紙幅の関係上, 各判例に関する紹介や 考察については限定的なものとならざるを得ない点, あらかじめお断りしておく。

\section{II. 租税法 ${ }^{11}$}

\section{1. 一時払終身保険の保険概念該当性を巡るアメリカの一判例}

ここでは, Old Colony Trust Co. v. Commissioner of Internal Revenue,

「貨物保険約款の英国法準拠法条項の解釈」前掲注8) 220～221頁。神戸地判昭 和45年 4 月 14 日判夕 288 号 283 頁, 評釈, 増田史子「保険代位の準拠法」前掲注 8) $222 \sim 223$ 頁。

10）ここでは，わが国の独占禁止法上の概念に倣って「審決」という語を用いて いるが, 正しくは「行政処分」, 原語に即してさらに厳密に言えば「行政処罰 (行政处罚)」という。

11）令和元年 9 月18日の日本保険学会関東部会報告では, 東京高判平成26年 9 月 
102F.2d 380（1939）を取り上げる。わが国の生命保険会社が取り扱う生命 保険契約 ${ }^{12}$ としては, 生存 (年金) 保障と死亡保障が 1 つの契約の中で一 体となったものが少なくないところ，本件で問題となった「生命保険契約」 についても，終身年金保障と死亡保障が 1 つ契約の中において一体のもの として構成されていた。そして，本件では，後者の保障に基づいて支払われ た金銭に対して, 当時の1926年歳入法302条 $\mathrm{g}$ 項 ${ }^{13)}$ が定めていた遺産税に係 る非課税枠の適用があるかどうかが争われたが，第 1 巡回区連邦控訴裁判所 はその適用を否定した。この点に関連して，本件判決，さらには，終身年金 保障と死亡保障が別々のものとしてセット取扱いされていた契約が問題とな った1941年の連邦最高裁判決（本件判決同様，死亡保障に基づいて支払われ

11日判時2242号56頁，金判1454号27頁についても取り上げたが，紙幅の関係上， 本稿では，その紹介㧍よび考察を割愛する。本判例では，年金支払特約が付加 された死亡給付金請求権（受給権）（ただし，保険契約者兼被保険者は年金種 類および年金支払期間の指定を行わず，その死亡後，死亡給付金受取人がそれ らを決定した）を相続税法上どのように評価するかが争われた結果，納税者勝 訴，国敗訴の判決が確定した。これを受け，課税庁は，年金の方法により支払 いを受ける保険金の支払請求権（受給権）の相続税法上の評価の取扱実務を変 更することとなったという点で，本判例は重要である（佐藤英明「租税法判例 の動き」ジュリ1479号『平成26年度重要判例解説』201頁以下（2015年）203頁 参照)。

12）後述するように，この項の論述では，そもそも“生命保険契約”とは何かが重 要な問題となるが，ここではさしあたり，わが国の生命保険会社が取り扱う商 品ないし契約を指すものとして, 生命保険契約という語を用いる。これ以降, “生命保険契約”とは何かという論点を含む文脈で用いる場合は，鍵括弧付きの 「生命保険契約」という語を用いる。

13）原文㧍よび日本語訳は次のと扔り。なお，日本語訳は，㴊圭吾「租税法にお ける生命保険契約の意義一一時払い養老保険・終身保険は相続税法 3 条 1 項 1 号にいう「生命保険契約」なのか? 一」金子宏＝中里実＝J.マーク・ラムザ イヤー編『租税法と市場』237頁以下（2014年・有斐閣）243頁に従った。 (原文)

"The value of the gross estate of the decedent shall be determined by including the value at the time of his death of all property, real or personal, tangible or intangible, wherever situated- 
研究対象としての保険判例の射程に関する一視点

た金銭に対する非課税枠の適用を否定) ${ }^{14)}$ 等を踏まえ, 租税法学界から保険 法学界に対して「生命保険契約」の意義を問いかける渕圭吾教授の論稿 ${ }^{15)}$ が存する（詳細は後記 II - 1 - c 参照)。

\section{a. 事実の概要}

イブレット・モルス（Everett Morss）という63歳（申告ベース）の人物 は, 1928年 8 月27日, カナダのサン・ライフ保険会社 (Sun Life Assurance Company of Canada）との間で, 大要, 次のような内容の「生命保険契約 (policy)」を締結した。

・モルスは,サン・ライフ社に対し，一時払保険料（a single premium）として 4 万2000ドルを支払う。

・サン・ライフ社は, 年金受給者（annuitant）たるモルスに対し, 終 身，毎年1400ドルの年金を支払う。

・サン・ライフ社は, モルス死亡時, 保険金受取人（beneficiaries, モ

(g) To the extent of the amount receivable by the executor as insurance under policies taken out by the decedent upon his own life; and to the extent of the excess over $\$ 40,000$ of the amount receivable by all other beneficiaries as insurance under policies taken out by the decedent upon his own life."

(日本語訳)

「故人の総遺産の価值は, 不動産・動産, 有形・無形を問わず, 故人の死亡 時における全財産を含むものとして決定される。

（g）故人が自らの生命についてかけていた生命保険契約に基づき遺産管理人 が保険金として受け取るべき額 ; 故人が自らの生命についてかけていた生命保 険契約に基づき故人以外の保険金受取人が保険金として受け取るべき額のうち 4 万ドルを超える部分」

14) Helvering $v$. Le Gierse, 312 U.S. 531 (1941).

保険法学界で, この1941年連邦最高裁判決に言及した論稿として, 梅津昭彦 「米国における生命保険規制一金融商品としての『保険』概念一」文研論集83 号139頁以下（1988年）がある。なお，本稿は，主に1939年に出された本件判 決を取り上げたが, 先例としての参照価值は, 圧倒的に1941年連邦最高裁判決 の側にある点 (渕・前掲注13) 239, 252頁), 留意を要する。

15）㴊・前揭注13)。 
ルスの子 3 名）に対し，(1) 4 万ドルに加え，1400ドルに最瑷の年金支 払時から死亡時までの期間に相当する割合を乗じたもの，あるいは，

(2)払込保険料から支払われるはずだった年金の総額を控除したもの， のうち多い方を支払う。

モルスは，上の契約締結から 5 年 4 か月を経過した1933年12月27日に死亡 した。これを受けて, サン・ライフ社は, 保険金受取人に対し， 4 万0994ド

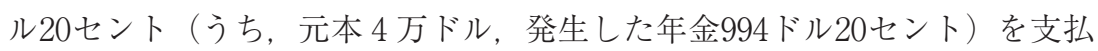
った。

遺産管理人（executor）ら申立人は, 当時の1926年歳入法302条 $\mathrm{g}$ 項に基 づき，4万ドルを非課税枠と取り扱って遺産税（estate tax）の申告を行っ たが、課税庁は, 上の契約が, 非課税枠の適用を受ける保険契約（a policy of insurance）でなく年金契約（an annuity contract）であるとして，申立人 による非課税枠適用を否認した。

こうした課税庁の判断について, 租税訴願庁 (the United States Board of Tax Appeals）も正当と認めたことから，申立人が上訴したのが本件である。

\section{b. 判 旨}

争点は，上の契約が，「生命保険契約なのか，それとも，年金ないし投資 契約なのか (whether the contract described above was a contract of life insurance or an annuity or investment contract)」ということであり，第 1 巡回区連邦控訴裁判所は, 大要, 次の趣旨を述べて租税訴願庁の判断を維持 した。

・保険契約（a contract of insurance）とは, 一般に, 一方当事者が, 他 方当事者に生じた特定の不慮の出来事あるいは災厄（a specified contingency or peril）による損失（loss）（これらはリスク（risk）と呼 ばれる）の補償を引き受けるものである。生命保険契約（life insurance）の場合, その不慮の出来事とは, 被保険者の死亡である。し かし, 本件契約（the contract）は, 生命保険契約としての必須の要 
研究対象としての保険判例の射程に関する一視点

素（essential requisites）を示していない。すなわち，保険会社は， 誰かの損失の補償を引き受けているわけではなく, 被保険者の死亡と いう出来事は，元本返済の時期および相手方を決定するに過ぎない16)。

・申立人は, この「生命保険契約 (policy)」が年金の特徵（an annuity feature）と生命保険の特徵（a life insurance feature）を併せ持って いるのであって，被保険者の死亡に伴って基本金額（principal sum） の支払いを約定している限りにおいて, それは生命保険契約（a contract of life insurance) であると主張する。しかし，この主張は正し くない。なぜなら, 保険会社の負う債務（obligations）は投資の特徵 （the investment feature）が支配的であり，これが本件契約（the contract）の性質（character）を決定しているからである ${ }^{17)} 。$

\section{c. 若干の考察}

本件判決は，終身年金保障と死亡保障を併せ持つ一時払終身保険から支払 われた死亡保険金につき, 当時の1926年歳入法302条 $\mathrm{g}$ 項が非課税枠適用要 件として定めていた保険概念, より具体的には, the amount receivable（by all other beneficiaries） as insurance under policies の該当性を否定した。従 来, 保険かどうかの区別に関するわが国の議論の具体例としては, 自家保 険・キャプティブ，ファイナイト保険等が挙げられてきたように思われる が ${ }^{18)}$ ，本件判決の特徴は，一時払終身保険（から支払われた死亡保険金）と いう，保険であることが一見自明とも言えそうな存在の保険概念該当性を否 定した点に求められる。つまり, 本件判決は, 保険概念該当性につき, 形式 的な議論でなく，あくまでも実質的な議論に基づいて評価したものと理解す ることができる。

この点, 保険の概念ないし定義に関する実質的な議論は, わが国にも従来
16) 102 F.2d 382 .
17) 102 F.2d 383.
18）山下·前掲注6) 15～21頁。 
から存在するものの ${ }^{19)}$ ，「保険の定義として普遍的に承認されているものは ない」 ${ }^{20)}$ とされる。しかし，例えば，山下友信教授は，改正前商法の下での 議論に打ける保険の定義につき, その要素を, (1)一方当事者の金銭の拠出 (保険料)，(2)他方当事者の偶然の事実の発生による経済的損失を補てんする 給付（保険給付)，(3)この(1)と(2)が対立関係に立つ，という3つに整理した うえ，(2)の中に保険契約者から保険者へのリスクの移転を読み込んでいる ${ }^{21}$ 。 こうした観点からすれば，本件判決とわが国の実質的な議論との間には，一 定の親和性が認められるようにも思われる。そして, 前述したように, 㴊教 授は, 租税法学界から保険法学界に対して, 次のような問いかけを行ってい $3^{22)}$ 。

[中略]アメリカでは人の死亡を保険事故とする保険が生命保険とされるのに対 して，日本では「人の生存又は死亡」が保険事故であるような保険契約が「生命 保険契約」とされる（保険法 2 条 8 号)。[中略]人は, 生存しているか死亡してい るかどちらかであるから，「被保険者」の生存と死亡の両方が保険事故とされる場 合には，結局のところ「被保険者」は移転すべきリスクを持ち合わせていないと 言えるかもしれない。[中略]にもかかわらずこうした契約が「保険契約」しか も「生命保険契約」とカテゴライズされているのである。

[中略]学問的な認識を行う法学研究においては，‥規制当局の立場とは独立に, 法的な概念を厳密に定義してしかるべきであるように思う。「保険契約」や「生命 保険契約」についても，それらが何を意味するかについて，保険法独自の問題と して，しっかり検討するべきではないか。そして，保険契約と年金契約ないし定 期金契約との関係を理論的に整理するべきではないだろうか。

19）例えば，平成21年度日本保険学会大会の共通論題は，「保険概念の再検討」 であった（保険学雑誌 609 号所収の大城裕二, 家森信善, 安井敏晃, 大倉真人, 後藤元の各論稿を参照)。

20）山下·前揭注6) 3 頁。

21）山下·前掲注6) $7 \sim 9$ 頁。

22）渕・前掲注13) 253 255頁。 
研究対象としての保険判例の射程に関する一視点

このように述べたのは，租税法律の規定が私法上の概念を用いている場合に， それらを解釈するに際しては，それらが原則として私法の世界における意味内容 を参照しているものと考えざるをえないからである。[以下略]

以上のように，日本の相続税法の解釈論としては私法上の概念の意味内容が参 照されると解さざるをえないため，保険法における「保険契約」・「生命保険契約」 といった概念につき機能的見地から厳密な定義を与えてもらうことを祈るしかな い。[以下略]

㴊教授が述べる「日本の相続税法 (の解釈論)」とは, 同法 3 条 1 項 1 号 にいう「生命保険契約」が「保険業法…第 2 条第 3 項…に規定する生命保険 会社と締結した保険契約…その他の政令で定める契約をいう」と定義されて いる部分を指すものと考えられる ${ }^{23)}$ 。現状, この定義は主として形式的側面 から構成されているため, 上で述べたような実質的な議論が進展しなければ 租税実務あるいは保険実務に対して直接的な支障が及ぶということには必ず しもならないものの ${ }^{24)}$, 㴊教授の問いかけについては, 保険法学界としても, 学問的見地から十分留意しておく必要があるように思われる。

\section{III. 競争法}

ここでは, 傷害保険のカルテルを巡る中国の一審決を取り上げるが $(\mathrm{III}-2)$, それに先立って, 中国の独占禁止法（反垄断法）（以下, 単に中国独禁法と いう）の概要につき，本稿に必要となる限りで説明する（III-1）。

23）また，相続税法施行令 1 条の 2 を参照。

24）この点, 山下·前掲注6)34頁は, 養老保険や終身保険といった生命保険につ き，それらが貯蓄ないし投資取引としての性格をもつことを前提としつつ， 「わが国に限らないが, 私法の面でも監督法の面でも, 基本的には生命保険も 保険であることには変わりはないというのが一般的な理解である。換言すれば, 保険の概念は，生命保険のようなリスクの移転に加えて，貯蓄ないし投資の側 面を一体化した独特の取引を包含するものである」と述べる。 


\section{1. 中国独禁法の概要 ${ }^{25}$}

中国独禁法は，2007年 8 月30日に制定公布され，2008年 8 月 1 日より施行 された ${ }^{26)}$ 。施行日を基準にすると，約11年が経過したところである。

世界の競争法は大きくアメリカ型（裁判と判例中心の法体系）と EU 型 （行政と行政ルールの法体系）に分けられるところ，中国独禁法は $\mathrm{EU}$ 型で あるとされる(なお，わが国の独禁法はアメリカ型である） ${ }^{27)}$ 。その中国独 禁法は，全 8 章，57か条で構成されており ${ }^{28)}$ ，具体的には次のような章立て となっている。すなわち, 第 1 章・総則，第 2 章・独占合意，第 3 章・市場 支配的地位の濫用，第 4 章・企業結合，第 5 章・行政権力の濫用による競争 の排除又は制限（以下，行政独占という表現を用いる），第 6 章・独占行為 に対する調査，第 7 章・法律責任，第 8 章・附則，である ${ }^{29)}$

このうち， III- 2 で主に問題となる第 2 章・独占合意は，禁止行為として， (1)価格の固定又は変更，(2)生産又は販売数量制限カルテル，(3)市場分割，等 の競争事業者間の水平合意（13条）と再販売価格の固定等の取引事業者間の 垂直合意（14条）を例示し（なお，15条は，これらに対する適用免除要件を 定めている)，さらに，事業者団体によるこれらの独占合意の組織も禁止す る $(16 \text { 条 })^{30)}$ 。そのうえで，事業者によるこれらの独占合意に対する法律責

25）中国独禁法につき，具体的事例を含め，その全体像を概説する論稿として, 川島富士雄「連載講座 中国独占禁止法一法運用と競争政策の行方一(第 1 回 第12回)」公正取引805号48頁以下，806号23頁以下 (以上，2017年），807号62頁 以下，808号35頁以下，809号52頁以下，811号73頁以下，812号54頁以下， 813 号52頁以下，814号57頁以下，816号58頁以下，817号61頁以下，818号33頁以下 （以上，2018年）がある。本稿III-1の論述についても，同論稿に多くを負って いる。

26）川島・前掲注25)第 1 回48頁。

27） 岸井大太郎 $=$ 大槻文俊 $=$ 和田健夫 $=川$ 島富士雄 $=$ 向田直範 $=$ 稗貫俊文 $\sqrt[\text { 経済 }]{ }$ 法一独占禁止法と競争政策一(第 8 版補訂)』（2019年 - 有斐閣）462頁 [稗貫執 筆]。

28）川島・前掲注25)第 1 回50頁。

29）川島・前掲注25)第 1 回50 51頁。

30）川島・前掲注25)第 1 回51頁。より詳しくは，川島・前掲注25)第 5 回52～54 
研究対象としての保険判例の射程に関する一視点

任につき, 第 7 章の46条 1 項は, 行政上の執行手段として, (1)排除措置命令, (2)違法所得の没収，(3)制裁金（前年度売上高の 1 10\%の範囲で（46条 1 項), 違法行為の性質, 程度及び持続した時間等の要素を勘案して裁量的に 決定 (49条)）を定めている ${ }^{31)}$ 。

なお，第 5 章・行政独占は，欧米や日本で見られない規定であり，その禁 止対象は, 行政機関等による(1)購入先指定等 (32条), (2)商品の地域間自由 流通の妨害 (33条), (3)差別的品質要求等による地域外事業者による入札へ の参加の排除又は制限 (34条), (4)不平等待遇等による地域外事業者の当該 地域での投資又は支店設立の排除又は制限（35条），(5)事業者に対する本法 の規定する独占行為の強制 (36条), 6行政権力の監用による競争排除又は 制限的規定の制定（37条）である（このうち，(2)から(4)は，地域保護主義あ るいは地域封鎖と称される) ${ }^{32)}$ 。中国において，こうした禁止行為が定めら れることとなった背景は，概ね次のようなものである。すなわち，改革開放 政策の方針を打ち出した1978年中国共産党第11期 3 中全会のコミュニケは, 経済管理体制に関する中央政府への権限集中という問題を踏まえて，地方に 経営管理自主権を委譲する等の対応を行ったが, こうした対応には, 地方に よる分割あるいは地域封鎖を助長するというマイナス効果も生じたことから， その対策として，違法な行政独占という考え方が導入されたのであった ${ }^{33)}$ 。

\section{2. 傷害保険のカルテルを巡る中国の一審決 ${ }^{34)}$}

ここでは, 具体的に, 中国太平洋人寿保险等 12 社による建設工程傷害保険

頁。

31）川島・前掲注25)第 1 回51頁。より詳しくは, 川島・前掲注25)第 5 回56 57 頁。

32）川島・前掲注25)第 1 回51頁。

33）陳暁菊「中国における行政独占の法規制 (一)」名古屋大学法政論集 263 号289 頁以下（2015年）299～301頁。

34）「審決」という語について, 前掲注10)参照。以下, 「行政処分」という語を 用いる。 
の市場分割カルテル事件（湖北省工商行政管理局・競争執法公告2015年第13 号 ${ }^{35)}$ )を取り上げる。

\section{a . 事実の概要}

中国太平洋人寿保险股份有限公司湖北分公司（以下，当事会社という）は, 湖北省において人寿保険，健康保険，傷害保険等の保険業務等を営んでいた。 2008年 1 月 1 日，当事会社は，泰康人寿保险股份有限公司湖北分公司等の 同業他社11社（以下，単に11社という）および武漢建築安全技術相談セン夕 一（以下，単に相談センターという）と「建設工程傷害保険 ${ }^{36)} に$ にかる共 同保険協議書（建设工程意外伤害保险共保协议书）」（以下，この共同保険の ことを本件共同保険，この協議書のことを本件協議書という）に共同で調印 し，これによって「武汉市建设工程人意险共保体」（以下，本件共保体とい

う）が成立した。本件協議書の主な内容は次のとおりであった。

・当事会社(甲)を首席保険者，11社(乙)を一般共同保険者，相談セン夕 一(丙)を本件共同保険管理責任者とする。

-共同保険者は甲乙双方，保険契約者は武漢市直轄の建設工程に携わる 企業，被保険者は当該各企業の作業員のうち18～65歳の者とする。ま た，丙は，本件共同保険にかかる安全専門技術サービスを提供する。

- 本件共同保険の原則は, 統一標準, 統一管理, 密接協力, 規範経営, 比例分配，リスク共担，費用分担，利益均等受領とする。

35）行政処分決定書（行政处罚决定书）の原文については，以下の URL を参照 （非価格独占合意に関する当時の独占禁止法執行機構（中国独禁法 10 条 1 項参 照）であった国家工商行政管理総局の URL が参照できなくなったため, 北京 盈科律师事务所の URL を引用。な押, 2018年 4 月から, 独占禁止法執行機構 は，新設された国家市場監督管理総局によって担われている（川島・前掲注 25) 第12回37 38頁))。

http ://www.antimonopolylawyer.com/show_news.aspx?d $=687$

36） あらためて後述するが，日本の保険法の分類に照らすと，この建設工程傷害 保険は「傷害疾病定額保険契約」（同法 2 条 9 号）に属するものと考えられる。 
研究対象としての保険判例の射程に関する一視点

・引受保険額は, 甲 $12 \%$, 乙各 8 \% とする。

・甲は, 保険料収納, 保険証券発行等の事務を一括して遂行したうえ, 毎月乙の各振込口座に保険料を振り込む。

・乙は，甲に対し，管理費用として収入保険料の 5 \%相当額を支払い, 甲乙双方は，丙に対し，サービス費用として収入保険料総額の $25 \%$ を 支払う。

・甲は，損害調査や保険金支払いの事務を遂行する。ただし，最終的な 保険金の負担については，引受保険額比例とする。

・本件共同保険にかかる連携システムを構築し，定期的に共同保険会議 を開催し, 必要に応じて本件共保体に存する問題を研究する。

また，本件共保体の各当事者は，「共保服务奖励与处罚的自律公约」等の 一連の管理制度を制定し，これらは，相談センターによる指導・監督の下で 執行された。なお，こうした中，相談センターは，武漢市建設委員会に関す る公共事務を管理する職能を有する組織 ${ }^{37)}$ となるに至っていた。

その後，この建設工程傷害保険への加入は，建築業者が「施工許可証（施 工许可证)」を得るための前提条件とされることとなった。

\section{b. 当事会社に対する行政処分理由}

1. 共同保険は, 保険業界において広く用いられる一種のリスク分散手法で ある。この点, 法律によって認可されている共同保険は, ある保険会社 が単独で保険を引き受けるにはリスクがあまりにも大きい人工衛星（卫 星发射）保険等，その具体的な内容があらかじめ決められているのであ って，これらは，競争回避行為に当たらない。しかし，当事会社におい ては，保険契約者と保険契約を締結する前に，建設規模，施工難易度， 施工人員数について不知のため, 事故発生の蓋然性を予測することは難 しく，そのリスクも判断しがたいことから，他社と協力して共にリスク

37）中国独禁法32～36条参照。 
を分担し，共に利益を享受する必要性は存しない。本件共保体は，法律 によって認可された共同保険ではない。本件共同保険行為（共保行为）

は，保険会社全 12 社が武漢市直轄の建設領域に入り込み，競争による損 害を回避しつつ各社が利益を確保したいという目的の下に行われたので あって，これは，競争回避行為に当たる。

2. 当事会社および11社はいずれも，傷害保険の引受資格を有する会社であ るところ，それぞれの会社は競争関係にある。当事会社は，11社および 相談センターと協議して本件共保体を成立させることにより，武漢市管 理の建設工程領域における傷害保険市場の分割を実行した。こうした行 為は, 当該領域における保険業務の正常競争秩序を乱し, 建築業者や他 の保険会社が当該市場に参入する利益を損なうものであって, 最終的に は消費者の利益を損なうものである。さらに，2011年に改正された建築 法（建筑法）は，傷害保険への加入を必須から奨励（鼓励）に改め, 各 企業が当該保険に加入するかどうかを選択することができることとした 状況に扔いて，当事会社が，当該保険への加入につき，建築業者が施工 許可証（施工许可证）を獲得するための前提条件としたのは，法律の規 定を無視するものであって，市場の公平競争システムを大きく歪曲した。

以上のとおり, 当事会社および11社の行為は, 中国独禁法 13 条 1 項 3 号に 違反する。したがって，同法46条 1 項に基づき，当事会社を以下のとおり処 分する。

\section{c. 当事会社に対する行政処分決定}

1．本件に㧍ける違法行為をただちに停止せよ。

2 . 本件共同保険にかかる違法所得 91.40 万元を没収する。

3 。制裁金として，2013年度の保険料収入額108.90万元の $6 \%$ にあたる 6.53 万元を支払え。 
研究対象としての保険判例の射程に関する一視点

\section{d. 若干の考察}

本件 ${ }^{38)}$ は, 人寿保険会社による建設工程傷害保険の市場分割カルテル事

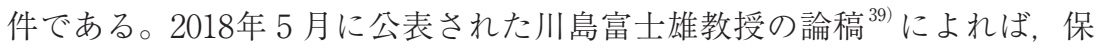
険を巡る市場分割カルテル事件が計 8 件存在する。そのうち 6 件は, 地方の 保険業協会が組織した事案，残りの 2 件は，人寿保険会社が組織した事案で あり，本件は後者のうちの 1 件である（後者の他の 1 件は, 江西省工商行政 管理局・競争執法公告2016年第 1 号事件 ${ }^{40)}$ である)。以下，順に考察する。

第 1 に，本件で問題となった建設工程傷害保険は，太平洋ホールディング

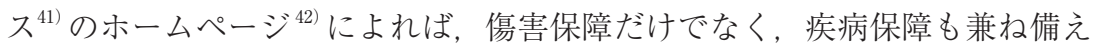
ているようであり（普通伤害+突发疾病），日本の保険法の分類に照らすと， 「傷害疾病定額保険契約」（同法 2 条 9 号）に属するものと考えられる。

第 2 に, 市場分割カルテルという手段については, 次のように分析するこ とができるものと思われる。すなわち，まずもって，人口世界一の中国にお ける保険市場の規模および成長度は極めて大きい。例えば，中国最大手の中 国人寿の 2017 年末主要指標を見ると，総資産46.8兆円，収入保険料8.2兆円， 基礎利益8520億円である ${ }^{43)}$ 。一方，わが国の日本生命保険相互会社（2017年 度連結ないしグループ）の場合，それぞれ74兆3925億円， 5 兆4220億円，

38）本件の評釈として, Dr. Zhan Hao \& Song Ying, Chinese Antitrust Agency Imposes Fines for Coinsurance (以下の URL を参照)。http://www.mondaq. com/redirection. asp? article_id=471420\&company_id=24920\&redirectaddress =http\%3A//en.anjielaw.com/downloadRepository/d418f17f-16d0-4737-aae4-9bf 5b82a8d5f.pdf

39）川島・前掲注25)第 6 回77～78頁（表 2)。

40）行政処分決定書（行政处罚决定书）の原文については，以下のURL を参照 (注35)と同様の理由により，个人图书馆の URL を引用)。

http://www.360doc.com/content/16/1006/14/9851038_596166756.shtml

41）太平洋人寿はこの买下に位置する会社である。

42） http://www.cpic.com.cn/c/2017-12-15/1254292.shtml

43）住友生命調べ。なお，中国人寿保険市場を分析した論稿として，例えば，藤田 圭一「開放に向かう中国生命保険市場」PRI Discussion Paper Series（No. 18A06）（2018年・財務省）。 
7227 億円という状況 ${ }^{44)}$ であるから, 総資産の面では日本生命が上回ってい るものの，収入保険料や利益の面では既に中国人寿が上回っている。さらに， 主な人寿保険会社の既契約者数は, 中国人寿 4 億人 (2015年度末), 中国平 安5200万人 (これ以外に法人 206 万社), 太平洋ホールディングス 1 億 1153 万 人，新華人寿 2966.4 万人（これ以外に法人 4.3 万社）という状況 ${ }^{45)}$ で，まさ に桁違いであると言える。こうした中, 筆者としては, 市場分割カルテルと いう手段は，原則として，“保険制度の健全性確保に相反する不合理なもの” であると考えている。なぜなら, 当該手段は, 自社の引受範囲ないし担当領 域以外の顧客に対し，100\%の確率で自社の保険商品を販売することができ ないということを含意するのであって，こうした事態は，保険群団の規模や 成長という保険制度の基本的要請に矛盾すると考えられるからである。それ にもかかわらず，当事者たる各保険会社が市場分割という手段を採用した， あるいは，採用することができたのは，必要性の観点から，「保険会社全 12 社が武漢市直轄の建設領域に入り込み…たい（12家保险公司都想介入市直建 设领域）という目的」を有していたためではないか，あるいは，許容性の観 点から，各保険会社が，こうした手段を採用しても大数の法則に反しない程 度の多くの既契約者数を抱えているためではないかと考えられる。言い換え れば，少なくとも後者の観点からは，本件カルテルは中国の保険市場だから こそ採用可能であったということになる。現に，中国以外の国で見られる保 険カルテルは, 市場分割カルテルでなく，ほぼ共通して，価格カルテル（保 険料率カルテル $)^{46)}$ であるように思われる ${ }^{47)}$ 。例えば, $\mathrm{EU}$ 主要加盟国であ

44）日本生命保険相互会社ホームページ。

45）住友生命調べ。

46）価格カルテル（保険料率カルテル）は，保険群団の規模や成長に対して直接 的に影響を及ぼさず，各社の営業努力によって他社を上回る営業成績（=規模, 成長) を挙げ得る手段ということができる。

47）川島・前掲注25)第 6 回79頁（表 3 ）によれば, 中国でも，浙江省自動車保 険料率等カルテル事件 (発改委行政処罰決定書 [2013]4，7～29号) (2013年12月 30日決定）という価格カルテル事件が見られている。 
研究対象としての保険判例の射程に関する一視点

るドイツについて, ある論稿は,「19世紀後半の時点で, ドイツの保険事業 者団体は，それぞれ分野別に創設されていたとされる。各保険事業者団体は, 特に会員各社の利益を確保する目的の下に，共同の最低保険料，団体として のタリーフの設定（Verbandstarife：つまり, Prämienkartelle（保険料カル テル），そして，共通の取引約款の作成などに注力していた」と到と述べる。 アジアに目を向けると, ベトナムでは, 2010年 7 月, 自動車保険料の価格カ ルテルについて, ベトナム国内の損害保険会社19社に対して総額17億ベトナ ムドンの制裁金が課された事例が見られている る論稿は，2007年 6 月14日，損害保険業界の料率談合に関して，同国公正取 引委員会の全員会議の議決により, 同国内の損害保険会社10社に対して総額 508億ウォンの課徴金が課された事例に言及している50)。そして，わが国に おいても, 保険カルテルの事件が見られている。すなわち, 最三判平成 17 年 9 月13日民集59巻 7 号1950頁は, 日本機械保険連盟が行った保険料率カルテ ルに関し，同連盟に加入していた損害保険会社 21 社に対して課徴金が課され た事例を取り扱っているのである（なお，当該事案の争点は，課徴金額の算 定の基礎となる売上額の意義であつた $\left.{ }^{51)}\right) 。$

第 3 に，本件市場分割カルテルの違法性について，ごく簡単に考察する。 本件は，武漢市の建設工程傷害保険という関連市場において，市場分割 ${ }^{52)}$

48）佐藤雅俊「EU 法によるドイツの「保険カルテル法」の改正への動因につい て」生命保険論集196号85頁以下（2016年）87頁。

49）経済産業省『新興国等における競争当局の執行状況に関する調査報告書』67 頁 (2017年)。

50）池光雲「保険業に対する公正取引法の適用除外法理に関する小考一米国・日 本・韓国の比較を中心に一」関西大学法学研究所ノモス 29 号 143 頁以下 (2011 年) 144 頁。

51）岡田豊基「損害保険料率カルテルを巡る課徴金の算定における売上額の意 義」神戸学院法学36巻 $3 \cdot 4$ 号25頁以下 (2007年)。

52）市場分割カルテルがハードコアカルテルに含まれるという理解は, 国際的に も共有されている（公正取引委員会競争政策研究センター「非ハードコアカル テルの違法性評価の在り方」 7 頁 [泉水文雄執筆])。 
（中国独禁法13条 1 項 3 号）という競争回避 ${ }^{53)}$ の手段を用い, 同条 2 項にい う「競争を排除し, 又は制限する」違法な独占合意が行われたものと認めら れる。すなわち, 本件共同保険は, 保険契約者たる企業の側でなく，専ら当 事者たる各保険会社の側の事情ないしイニシアティブにより，「統一標準， 統一管理，密接協力，規範経営，此例分配，リスク共担，費用分担，利益均 等受領」（太字および下線は筆者による）という原則の下に実行された。他 方，本件共同保険が同法15条で定められた適用免除要件のいずれにも該当し ないことは明らかである ${ }^{54}$ 。したがって，本件行政処分が，その理由第 1 項 で述べたところに従い，本件市場分割カルテルについて同法13条 1 項 3 号該 当性を認定した点，妥当な判断であったと考えられる。

第 4 に, 本件で登場する武漢建築安全技術相談センターは, 武漢市建設委 員会に関する公共事務を管理する職能を有する組織となるに至っていたこと から，本件は行政独占事件 ${ }^{55)}$ としての性格も併せ持っている。本件は，こ うした意味においても，中国独禁法の特徵が色濃く出た事案であったと言え よう。

\section{N． 情報法}

ここでは，保険会社が監督官庁に対して提出した報告書に関する，行政機 関情報公開法に基づく開示可否を巡るわが国の一判例を取り上げるが（IV2)，それに先立って，わが国の行政機関情報公開法，比較法として若干後

53）独占禁止法違反行為は, 競争回避型の行為と競争排除型の行為に分けられる ことがあるが（岸井 $=$ 大槻 $=$ 和田 $=$ 川島 $=$ 向田 $=$ 稗貫 $\cdot$ 前掲注 27$)$ 10 11頁 $[$ 岸 井執筆])，本件行政処分がその理由第 1 項で明示しているように，本件は前者 に当たる。

54）宮川裕光『米国・ EU・中国 競争法比較ガイドブック』中央経済社 97 99 頁（2010年）は，少なくとも条文上，価格カルテルや市場分割カルテル等の水 平的独占合意に対しても同法15条が適用される余地がある旨を述べる。

55）この行政独占事件が別件処理されている旨は，本件行政処分決定書から読み 取れるものの，当該別件の詳細については公表されていない。 
研究対象としての保険判例の射程に関する一視点

述するイギリスの2000年情報自由法（Freedom of Information Act 2000）の 各概要につき, 本稿に必要となる限りで説明する $(\mathrm{IV}-1)$ 。

\section{1. わが国の行政機関情報公開法およびイギリスの2000年情報自由法の概要 a . わが国の行政機関情報公開法の概要}

行政機関情報公開法は, 国民主権の理念にのっとって, 政府がその活動に 係る説明責任を果たすとともに，公正で民主的な行政の推進に資することを 目的として $\left(1\right.$ 条), 何人にも, 行政機関 ${ }^{56)}$ の長に対する行政文書 ${ }^{57)}$ の開示 請求権を付与している ( 3 条)。開示請求を受けた行政機関の長は, 原則と して，その請求に係る行政文書の開示義務を負うが（５条），以下に例示す る情報（以下，不開示情報という）が記録されている場合には，全部不開示 （５条）または一部開示（6 条）とすることができる。

（1）個人に関する情報であって，特定の個人を識別することができるも の等 ( 5 条 1 号)

（2）法人等に関する情報であって，公にすることにより，当該法人等の 権利，競争上の地位その他正当な利益を害するおそれがあるもの（5 条 2 号イ) 等

（3）国の機関等が行う事務又は事業に関する情報であって，公にするこ とにより，当該事務又は事業の適正な遂行に支障を及ぼすおそれがあ るもの (5 条 6 号)

ただし，当該行政文書に不開示情報が記録されている場合であっても，行 政機関の長は，公益上の理由による裁量的開示を行うことができる（７条）。 逆に，当該行政文書の存否を答えることが不開示情報の開示となる場合，行 政機関の長は，その存否応答の拒否を行うことができる（８条)。

56）定義について，2 条 1 項参照。

57）定義について，2 条 2 項参照。 


\section{b．イギリスの2000年情報自由法の概要}

2000年情報自由法についても，何人にも情報開示請求権（right of access to information）が付与されており，一定の不開示事由（exemptions）に該 当しない限り，開示請求を受けた公的機関（public authority） ${ }^{58)}$ がその請求 に係る情報の開示義務を負う（1 条 1 項）という法構造は，行政機関情報公 開法と大きく変わらない。しかし，不開示事由の定め方は，両者で異なって いる。すなわち，行政機関情報公開法の不開示情報該当性は，5条各号によ る，いわば一段階テストによって判断されるのに対し，2000年情報自由法の 不開示事由は, 絶対的不開示事由（absolute exemption）と相対的不開示事 由の 2 こ区分されたうえ，後者については，「諸般の事情に鑑み，当該情 報を不開示とすることの公共の利益が当該情報を開示することの公共の利益 を上回るとき」( 2 条 2 項 $\mathrm{b}$ 号 ${ }^{59)}$ に該当して初めて不開示相当とされるこ とから，後者は，いわば二段階テストによって判断される。IV-2では，法 人に関する情報の不開示情報該当性を検討することとなるが，2000年情報自 由法は，法人に関する情報，具体的には，商業上の利益（commercial interests）として 43 条 2 項が定める不開示事由 ${ }^{60)}$ を後者に位置付けている。

58）ここでいう公的機関には，行政機関情報公開法と異なって，行政機関のほか, 裁判所や議会も含まれるという建前が取られている。

59）日本語訳は筆者による。原文は次のとおり。

"in all the circumstances of the case, the public interest in maintaining the exemption outweighs the public interest in disclosing the information."

60）原文および日本語訳（訳は筆者による）は次のとおり。 (原文)

"Information is exempt information if its disclosure under this Act would, or would be likely to, prejudice the commercial interests of any person (including the public authority holding it)."

(日本語訳)

「本法に基づいてある情報を開示することが，第三者（当該情報を保有する 公的機関を含む）の商業上の利益に損害を及ぼし又は及ぼすおそれがある場合 には，当該情報は不開示情報とする。」 
研究対象としての保険判例の射程に関する一視点

\section{2. 保険会社が監督官庁に対して提出した報告書の開示可否を巡るわが国の}

\section{一判例}

ここでは, 具体的に, 東京地判平成21年 5 月 21 日判例集等未登載 ${ }^{61)}$ 取 り上げる。本件において開示可否が争われた行政文書は, 当時の保険金支払 問題に関連し，各保険会社が監督官庁に対して提出した報告書である。

\section{a. 事実の概要}

本件は, X (原告)が, 平成18年12月11日, 処分行政庁（金融庁）に対し, 行政機関情報公開法（以下，判旨引用部分においては，単に情報公開法とい う）に基づてて 3 件の行政文書の開示請求をしたところ, 開示請求対象文書 にはそれぞれ同法 5 条 1 号本文， 2 号イおよび 6 号に該当する不開示情報が 記録されているとして，いずれも不開示とする決定を受けたことから，この 各不開示決定（ただし，異議決定により取り消された後のもの）は違法であ ると主張し，Y(国)を相手取って，これらの取消しを求めた事案である。

上にいう 3 件の行政文書とは，概ね次のような内容であった。

(ア) 平成17年10月28日付けA 1 生命保険会社に対する行政処分について のうち，支払いがされていない保険金等に関する個別具体的で詳細な 事例内容およびこれに関する一切の資料

(イ) 平成18年 7 月 26 日における A 2 生命保険会社に対する行政処分のう ち, 告知義務違反により会社が，保険契約を解除できる期限を経過し たにもかかわらず，事故者が解除期日を改ざんし，解除期限後に保険 契約を不正に解除していたことに関する個別具体的な詳細な事例内容 およびそれに関する一切の資料

(ウ) 平成18年 6 月21日におけるA3 損害保険会社に対する行政処分の,

個別具体的な詳細な事例内容およびそれに関する一切の資料

これに対し，処分行政庁は，各開示請求対象文書を次のように特定したう

61） 本件の評釈として, 大林啓吾 - 季報情報公開・個人情報保護35号39頁以下 (2009年)。 
え，平成19年 1 月 9 日，上の各規定を根拠として不開示決定を行った。

(ア) A 1 に対する検査に係る平成17年 8 月 8 日付け検査結果通知に対す る A 1 からの改善報告書（以下，本件行政文書 1 という）抽び「保 険金等支払管理態勢の実態把握及び不払事案に係る再検証」に係る保 険業法128条 1 項に基づく報告徵求命令に対する A 1 からの報告書 (以下，本件行政文書 2 という)

(イ) A 2 より提出のあった平成18年 7 月 26 日付け行政処分に係る不祥事 件届出書（以下，本件行政文書 3 という）拈よび同届出書に係る保険 業法128条 1 項に基づく報告徵求命令に対する A 2 からの報告書（以 下，本件行政文書 4 という)

(ウ) A 3 に対する検査に係る平成18年 4 月 6 日付け検査結果通知に対す る A 3 からの改善報告書（以下，本件行政文書 5 といい, 本件行政文 書 1 ないし 5 の各文書を併せて，本件各行政文書という）

$\mathrm{X}$ は，平成19年 3 月，上の各不開示決定を不服として，処分行政庁に異議 申立てを行った。これを受け，処分行政庁は，平成19年 6 月 1 日，情報公 開・個人情報保護審査会への諮問（行政機関情報公開法18条参照）を行った。 同審査会は，平成20年11月27日，概ね次の内容に限って開示を妥当とする旨 の答申（以下，本件答申という）をし，処分行政庁は，平成21年 1 月 23 日， 本件答申に沿った決定を行った。

- 本件行政文書 1 のうち, 改善報告書の表紙

・本件行政文書 2 のうち, 報告書の表紙および資料の一部[詳細略］

・本件行政文書 3 のうち, 不祥事件届出書の様式部分

- 本件行政文書 4 のうち, 報告書の表紙

-本件行政文書 5 のうち, 改善報告書の表紙および資料の一部[詳細略］

\section{b. 判 旨}

本件の争点は，上の各不開示決定（ただし，異議決定により取り消された 後のもの）の適法性であり，特に，不開示とされた情報に係る行政機関情報 
研究対象としての保険判例の射程に関する一視点

公開法 5 条 1 号本文, 2 号イおよび 6 号該当性が問題となった。裁判所は, 本件各行政文書に係るXの請求を棄却した。以下, 紙幅の関係上, 判旨のう

ち，本件行政文書 3 かつ同法 5 条 2 号イに関する部分のみ引用する。

$\ulcorner ア \quad$ 本件行政文書 3 の記録内容

（ア）本件答申によれば，本件行政文書 3 の本件不開示部分には，特定保険 会社の自主的な調査に基づき発生した不祥事件に係る非公表の事故者の 氏名, 事故の概要, 事故発生原因の分析 - 問題意識, 再発防止策等の内 容が記録されていることが確認されている。

（イ）そして，[中略]本件行政文書 3 は, 内閣緿理大臣等の監督事務の端緒 となる情報を提供するために，保険会社が義務付けられている不祥事件 が発覚した旨の届出書（不祥事件届出書）であるところ, 証拠及び并論 の全趣旨によれば，金融庁の指定に係る「不祥事件届出書」の所定の様 式には，A表題(不祥事件届出書)及びB) て名 (金融庁長官)が定型文言 で印刷され，(C)文書番号，(D)作成年月日， E)保険会社名及び代表者名 (印影を含む。), F保険会社名, G 事故発生支社・支部名等, (H)代理店 名（店主名）及び委託状況， I) 事故者の役職名及び氏名(生年月日及び 年齢), $\mathrm{J}($ 事故者の) 入社年月日, $\mathrm{K}$ 法令違反の該当規定 (法令に違反し ない場合は理由), (L)届出の根拠規定 (規則), (M) 保険会社が不祥事件の 発生を知った日， (N)発生期間，(0)事故金額(うち実損見込み)，( P) 発覚の 端緒 (日付を含めて記載する)，Q事故の概要， R事故の調査・解明の状 況， S 事後措置， (T)事故発生原因の分析 · 問題認識等, U 再発防止策, V 処分内容 (事故者・関係者)，W備考の各名称が付された記入欄が設け られていることが認められ，[中略]本件行政文書 3 は, A2 の本社の事 故者の不正な事務処理（保険契約の不正解除及び保険金等の支払に係る 遅延利息の過少支払）が発覚した旨を届け出たものであることからすれ ば， H) (代理店名(店主名)及び委託状況) 欄に記録があるとは考え難く, 特記事項がなければW(備考)欄には記録がされないと考えられることか

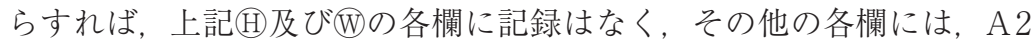


保険学雑誌 第 648 号

における上記の保険金等の不適切な不払の事案に関し，おおむね各闌の 名称に沿った情報が記録されているものと推認される。

イ 情報公開法 5 条 2 号 亿該当性

(ア）本件行政文書 3 には，上記アのとおり， 南及びツの各欄を除く各欄に は，おおむね各欄の名称に沿った情報が記録されていると推認されると ころ,これらの情報は, いずれも, A 2 において保険金等の不適切な不払 が発覚したことに関する情報であるから，そのような情報が，「法人等に 関する情報」(情報公開法 5 条 2 号本文) に該当することは明らかである。 そして, 上記各闌の記録のうち, $(\alpha) \mathbb{R}$ 事故の調査・解明の状況, 事故発生原因の分析・問題認識等, U 再発防止策の各欄には, A 2 にお ける保険金等の不適切な不払の発生原因及びその原因を踏まえた再発防 止策が記録されていると推認されるところ，[中略]A 2 における保険金 等の不適切な不払は，本社の事故者が保険契約を不正に解除したり，保 険金等に係る遅延利息を過少に支払うという事務処理をしていたことを 内容とするものである以上，上記発生原因及び再発防止策に係る記録に おいては, 当時の A 2 における支払管理態勢に関する情報や, 当該事故 者に対する内部機関の監視等といった経営管理態勢に関する情報が記録 されているものと推認されるところ, [中略]このような内部管理態勢に 係る情報は，A2において考案・構築されて蓄積されてきた社内のノウ 八ウというべきものであって，事柄の性質上，その詳細は公表されてい ないものと推認され，仮にそのノウハウが公表されて同種の業務を実施 する他の保険会社等に明らかになれば，A2の権利ないし競争上の地位 その他正当な利益を害する相当の蓋然性があることが客観的に認められ るというべきである。

また, $(\beta)$ P 発覚の端緒, $(\mathrm{R}$ 事故の調査・解明の状況, S 事後措置, ( T) 事故発生原因の分析・問題認識等及び $\mathrm{V}$ 処分内容(事故者・関係者)の 各欄には, A 2 における当該不祥事件の発覚の経緯, 当該不祥事件に対 する具体的な事後的対応策, 当該不祥事件の発生原因に係る分析内容並 
研究対象としての保険判例の射程に関する一視点

びに当該事故者及び関係者の具体的な処分内容が記録されているものと 推認され，これらの情報は，いずれも，A2 における不祥事件への対応 という危機管理態勢に係る当時の状況・態勢に関する情報であるといえ るし，また， (M)保険会社が当該不祥事件の発生を知った日及びQ事故の 概要の各欄には，A 2 が実際に当該不祥事件を知った年月日及びその当 時に把握していた当該不祥事件の具体的内容が記録されているものと推 認され，これらの情報も，A2 が当該不祥事件の発覚時に把握していた 事件の詳細及び不祥事件が発覚した時期など，A２における当時の危機 管理態勢及びその具体的な状況・態勢を推知することができる情報であ るといえるところ，このような情報も，[中略]A2における危機管理態 勢に関する情報であり，当該保険会社において不祥事件等が発生した場 合に, それによる損害を最小限に抑え, 迅速・円滑に損害の回復を眓る ベく, より実効的な態勢を形成するために考案・構築されて蓄積されて きた社内のノウハウというべきものであり, 事柄の性質上, その詳細は 公表されていないものと推認され, 仮にそのノウハウに関する情報が公 表されて同種の業務を実施する他の保険会社等に明らかになれば，A2 の権利ないし競争上の地位その他正当な利益を害する相当の蓋然性があ ることが客観的に認められるというべきである。

したがって，本件行政文書 3 のうち，上記 $(\alpha)$ 及び $(\beta)$ の各欄に記録 された情報は, いずれも情報公開法 5 条 2 号イに規定する不開示情報に 該当するものということができる。

（イ）この点に関し，Yは，本件行政文書 3 の本件不開示部分のうち，G事 故発生支社・支部名, $\mathrm{K}$ 法令違反の該当規定 (法令に違反しない場合は 理由)，(L)届出の根拠規定 (規則)， (N)発生期間及び@事故金額 (うち実損 見込み)の各欄の記録に係る情報についても，これらが明らかになれば， A 2 の事務管理上の問題点や経営状況について無用の憶測を招き，再発 防止に向けて努力を開始したA 2 の企業イメージや社会的信用が不当に 低下し，ひいては顧客が減少するなどの事態を引き起こしかねないとし 
て，これらの情報も情報公開法 5 条 2 号イの不開示情報に該当する旨主 張する。

しかしながら，本件行政文書 3 の上記各欄の記録に係る不祥事件が， A 2 の本社の事故者が行った保険契約の不正解除及び遅延利息の過少支 払によるものであることは，答弁書の記載から明らかであり，また，証 拠及び弁論の全趣旨によれば，A２は自社における保険金等の不適切な 不払の件数及び被害金額の合計を既に自ら公表していることが認められ， そうすると，既に公表済みの事項を含む上記 $\mathrm{G},(\mathrm{K}),(\mathrm{L}),(\mathrm{N}),(\mathrm{O}) の$ 各欄 の記録に係る情報を公表した場合に, A2 の事務管理上の問題点や経営 状況について無用の憶測を招くとのYの上記主張は, 本件の上記事実関 係の下では，直ちに採用し難く，Yの主張に係る「憶測」の具体的な内 容も必ずしも明らかでないことも併せ考えれば，Yの主張に係る上記各 欄の記録に係る情報が公表されることにより，A2 の企業イメージや社 会的信用が不当に低下し，ひいては顧客が減少するなどの事態を引き起 こす相当の蓋然性が客観的にあるとは認め難い。

（ウ）また，Yは，[中略]本件行政文書 3 の本件不開示部分の $\mathrm{E}$ 保険会社名 及び代表者名(印影を含む。) のうち社印及び代表社印の印影部分につい ても，情報公開法 5 条 2 号イの不開示情報に該当する旨主張するが, [中略]本件行政文書 3 の作成経緯等からすれば, [中略]上記印影部分が 公にされることによって，A2 の正当な利益を害するおそれがあると認 めるには足りないというべきである。

(工) [略］」

\section{c. 若干の考察}

本件行政文書 3 は, A 2 が, 保険業法 127 条 1 項 8 号, 同法施行規則 85 条 1 項17号に基づいて監督官庁（金融庁）に提出した報告書である。こうした 観点からすれば, 本件判決は, 講学上の保険法の主要な研究領域である保険 
研究対象としての保険判例の射程に関する一視点

監督法 ${ }^{62)}$ につき, これを情報 (公開) 法の側面から捉えたものと考えるこ ともできよう。

上の引用部分からも見て取れるように, 行政機関情報公開法に基づく行政 文書の開示可否を巡る事案（情報公開・個人情報保護審査会の答申を含む） では，事案ごとに，細部にわたる認定・判断が行われることが多い。こうし た中, 本件各行政文書の特徴は, A 1 A 3 の各保険会社にとって, いわば マイナス情報とも評すべき情報につき，保険業法に基づいて義務的に提出す ることとなった監督官庁あて報告書という点に求められよう。この点, こう したマイナス情報が記録された行政文書の開示可否が争われる場合には, 行 政機関情報公開法 5 条 2 号イにいう「当該法人等…の権利, 競争上の地位そ の他正当な利益」よりも，例えば，当該行政文書を開示することによる被害 者の救済や当該法人等の自浄作用発揮といった事柄が意識的に優先され得る のではないかという議論が考えられる。そして，現に，本件のXにおいても， 「本件各行政文書は，生命保険会社各社が本来支払うべき保険金を支払わな かった事案に関するものであり，当該法人等の正当な利益が害される余地は 皆無である。また, 当該保険会社に適切な経営管理のノウハウ等がなかった からこそ，保険金不払問題が発生したと考えられる」と主張している ${ }^{63)} 。 し$ かし，本件判決は，こうした主張に与することなく，一段階テスト（IV-1$\mathrm{b}$ 参照）に基づき，本件各行政文書中の各項目の「正当な利益」性を慎重に 認定・判断したものと評価することができる。

上と類似の判断要領は，イギリスの2000年情報自由法の下における審判例 でも見られる。Anthony Craven v. Information Commissioner, Appeal no $\mathrm{EA} / 2008 / 0002^{64)}$ がそれである。本件は，イングランド中部のウエスト・ブ

62）前掲注6)参照。

63）この点, 大林・前掲注61)44頁も, 「本件で対象となっている情報元は, 不払 事案や不祥事件に対する金融庁の検査に伴う文書である。この中に保険会社の ノウハウに関連する内容が含まれるからといって, それらを不開示とすること に正当な利益があるといえるだろうか」と述べる。

64) see, John MacDonald and Ross Crail, MacDonald on the law of freedom of 
ロムウイッチ（West Bromwich）に本拠を置く住宅金融組合（Building Society) ${ }^{65)}$ (以下，当該住宅金融組合のことをWBBS という）が販売した住宅 担保年金制度 (home income plans, 以下, HIP という) ${ }^{66)}$ を巡り，その運用 失敗に係る被害者支援団体の代表者（以下，C氏という）が，HIP 販売に 関する本件報告書を保有するイギリスの金融サービス機構（Financial Services Authority, 以下, FSA という) ${ }^{67)}$ に対し，本件報告書の開示を請 求したところ，FSA が当該開示請求に対して拒否処分を行ったことに端を 発する事案である。C 氏は，審判手続きにおいて，WBBSの商業上の利益 （commercial interests）につき, WBBS の行為や年金受給者への影響に鑑み

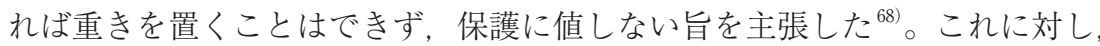
情報審判所（Information Tribunal）は，審判において明らかにすべき事柄 は，それが保護に值するかどうかではなく，法43条にいう（当該利益に損害 を与える）おそれ お帛があるかどうかである旨を明言したうえで70)，冷静に商 業上の利益の存在を認定し，さらに，問題となっている情報の開示に有利な 事情 ${ }^{71)}$ よりも，不開示に有利な事情のほうが重い旨を述べて（以上，二段階 テスト (IV - 1-b 参照))，不開示相当の決定（decision）を下した ${ }^{72)}$ 。比較

information, 3rd ed., 2016, pp. 504-505.

65）元来は，組合員からの投資を原資にして，組合員の住宅資金をその住宅への 譲渡抵当（mortgage）を担保にして貸与する法人。しかし，1986年法によっ て，現在では他の銀行業務をも行うことを認められている（小山貞夫編著『英 米法律語辞典』127頁 (2011年・研究社) )。

66）生命保険文化センター『2004 生命保険用語英和辞典』376頁（2004年）。

67）生命保険文化センター・前掲注66)309頁。

68) Anthony Craven v. Information Commissioner, Appeal no EA/2008/0002, para. 15.

69）前掲注60)参照。

70) supra note 68 , para. 41.

71）そのうちの 1 つには, 「HIP の販売に関する問題点を公にすることによって, 被害者救済，消費者教育，再発防止を後押しするという効果が認められる」 (supra note 68, para.47）という事情も含まれている。

72) supra note 68, para. 48-49. 
研究対象としての保険判例の射程に関する一視点

法の見地から参考になるものと思われる。

なお，本件各行政文書は，法令に基づて義務的に提出することとなった 監督官庁あて報告書であったが，監督官庁あてに任意で提出する文書に関し， 行政機関情報公開法 5 条 2 号ロは,「行政機関の要請を受けて，公にしない との条件で任意に提供されたものであって, 法人等‥における通例として公 にしないこととされているものその他の当該条件を付することが当該情報の 性質, 当時の状況等に照らして合理的であると認められるもの」を不開示情 報としている。実務において，保険会社が監督官庁に対して任意で文書を提 出することは少なくないと思われることから，この規定にはあらためて留意 しておく必要があろう。

\section{V. おわりに 一まとめと残された課題一}

以上, 本稿は, 学界の研究対象としての生命保険分野の判例件数が減少傾 向にあるという問題意識を踏まえ, その研究対象の裙野を拡げることを目的 に, その対応策の 1 つとして, 租税法, 競争法, 情報法という各周辺法分野 に関する判例の紹介および考察を行った。具体的には次のとおりである。

II-1では，一時払終身保険（から支払われた死亡保険金）につき，アメ リカの遺産税に係る保険概念該当性を否定した前出 Old Colony Trust Co. 事件を取り上げた。この事件に言及した論稿では，「生命保険契約」の意義 に関して, 租税法学界から保険法学界への問いかけも行われており, 今後の 議論にあたって参考となるように思われる。 III-2では, 中国の人寿保険会 社による建設工程傷害保険の市場分割カルテルを取り扱った前出湖北省工商 行政管理局・競争執法公告事件を取り上げた。市場分割カルテルという手段 が用いられたのは，中国の保険市場ならではの特徴と考えて差し支えないよ うに思われる。IV-2 では, 保険会社が保険業法 127 条 1 項 8 号, 同法施行規 則85条 1 項17号に基ついて監督官庁に提出した報告書の開示可否を巡る前出 東京地判平成21年 5 月 21 日を取り上げた。保険監督法の情報（公開）法的側 面と捉えることができよう。 
以上のような紹介および考察の結果，通常，それぞれ租税法，競争法，情 報法の分野に属すると考えられている各判例の中には，保険法学界として今

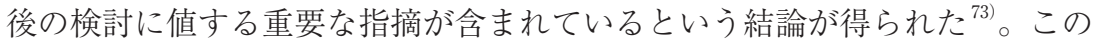
ことは, 講学上の保険法の研究を深化あるいは発展させていくにあたって, その他の周辺法分野も含めた保険判例を比較参照することが，有益な手法の 1 つであり得ることを示唆しているであろう。本稿が，こうした視点を提示 したことにより，今後の学界の発展に対してわずかでも貢献ができるとすれ ば，望外の喜びである。

もっとも, 本稿の研究成果を上のように理解した場合, 次のとおり, 残さ れた課題が存することとなる。すなわち, 本稿で取り上げた 3 つの周辺法分 野の中には，ほかにも保険判例として取り上げるべき事件があるかもしれな い。また，周辺法分野自体についても，上の 3 つに限らず，例えば，別冊ジ ユリスト『保険法判例百選』でも取り上げられている国際私法分野，さらに は，商事仲裁分野等，様々なものが考えられるであろう。この点については， 残された課題として，今後とも研究を進めてまいりたい。

(筆者は住友生命保険相互会社勤務，博士（法学））

73）直接的な判示事項ではない事柄の中にも，有益な検討材料があるように思わ れる。例えば，前掲注11)で言及した前出東京高判平成26年 9 月11日では，変 額個人年金保険に付加された年金支払特約の存在が認められたが，この特約に つき，(1)保険契約者が保険契約締結時に全項目を指定して付加した，(2)保険契 約者が保険契約締結時に付加したが，年金種類および年金支払期間の指定が行 われなかった（本件事案），(3)保険契約者は保険契約締結時に付加せず，保険 事故発生後, 死亡給付金受取人が付加・指定した, という各場合における保険 契約法上の性質の差異についても，検討に值するものと思われる。 